\title{
Sediment source identification and residence times in the Maroochy River estuary, southeast Queensland, Australia
}

\author{
G. Douglas · G. Caitcheon $\cdot$ M. Palmer
}

Received: 1 January 2008/Accepted: 10 April 2008/Published online: 29 April 2008

(C) The Author(s) 2008

\begin{abstract}
Identification of sediment sources and associated nutrients and contaminants is crucial to the ecological management of aquatic systems. A combination of geochemical and radionuclide tracing techniques and geostatistical modelling have been used to determine the primary source areas of fine sediment delivered to the Maroochy River estuary. The application of radionuclide $\left({ }^{137} \mathrm{Cs}\right.$ and $\left.{ }^{210} \mathrm{~Pb}\right)$ techniques indicate that approximately $70 \%$ of the sediment in the Maroochy River estuary originates from subsoil erosion. An average of $60 \%$ of sediment in the lower estuary originates from soils developed on the Landsborough Sandstone, with 35\% coming from soils developed on granitoids. In the mid-Maroochy River estuary major contributions of fine sediment come from soils developed on Landsborough Sandstone (38\%) and granitoids $(36 \%)$. Estimated sediment residence times in the Maroochy River estuary are generally less than 30 years, however, one sample site near the estuary mouth had an estimated residence time of at least 30 years. This indicates that sediment accumulation rates in mangroves along the estuary margins are relatively low. Results from this study will be used by catchment managers to better target remedial
\end{abstract}

G. Douglas $(\bowtie)$

CSIRO Land and Water, Centre for Environment and Life

Sciences, Floreat, WA, Australia

e-mail: Grant.Douglas@csiro.au

G. Caitcheon

CSIRO Land and Water, Black Mountain Laboratories,

Canberra, ACT, Australia

M. Palmer

CSIRO Mathematical and Information Sciences,

Centre for Environment and Life Sciences,

Floreat, WA, Australia action to reduce fine sediment delivery to the Maroochy River estuary.

Keywords Sediment $\cdot$ River $\cdot$ Estuary $\cdot$ Erosion · Modelling

\section{Introduction}

Identifying the sources of sediment delivered from catchments to receiving waters is essential to developing effective short and long-term management strategies. With this information catchment managers are able to prioritise and obtain maximum value from remedial work aimed at reducing the supply of sediment. Outcomes of sediment source identification may include more effective management of erosion and sediment transport (Douglas et al. 2005); reductions in sedimentation in tributaries or the receiving water bodies; reduced turbidity. A reduction in the transport of phosphorus and nitrogen may also be important in the occurrence of seasonal algal blooms in estuaries and in particular the Maroochy estuary given its proximity to the southern end of the World Heritage-listed Great Barrier Reef (Cloern 1996; Douglas et al. 2003a; Diaz-Pulido and McCook 2005; Hamilton et al. 2006).

This study investigates the location of primary source areas of fine sediment delivered to the Maroochy River estuary using geochemical "fingerprinting" and radionuclide tracing methods. The geochemical properties of fine sediment sampled from the estuary, and the fine silt and clay fraction of soils developed on the different rock types in the catchment are measured. The spatial sediment source tracing method makes use of the often unique geochemical properties of soils developed on different rock types. When soil is eroded and becomes transported sediment, it carries 
its inherited geochemical composition ("fingerprint" e.g. Collins and Walling 2004). The suite of elements chosen is based on both the contrast in concentration between different soil end members, and a knowledge of the soil mineralogy and hence element speciation with a view to the robustness of the inherent soil geochemical signature during transport and deposition. The sources or origins of the sediment can then be determined by "unmixing" the sediment geochemistry at some point in the drainage network, in this case the Maroochy River estuary. The "unmixing" is achieved, and quantitative proportions of catchment sediments determined, using a purpose-built Bayesian unmixing model (e.g. Douglas et al. 2005; Palmer and Douglas 2008). Analysis of the results in an "unmixing" model provides estimates of the relative proportions of sediment delivered to the estuary from the main source areas.

Measurements of surface tracing radionuclides were also undertaken to determine whether topsoils (e.g. sheet erosion) or subsoils (e.g. channel bank erosion) contribute most sediment to the Maroochy River estuary. Identifying the main erosion processes and spatial sources of fine sediment delivered to the Maroochy River estuary will allow catchment managers to more effectively target remedial action to reduce sediment delivery. Thus, the unmixing and erosion tracing techniques can be broadly linked to ascribe both a source area and the mode of erosion.

Fallout caesium-137 has been widely used to determine the erosion processes that generate sediment (Peart and Walling 1988; Walling and Woodward 1995; Wallbrink et al. 1999). ${ }^{137} \mathrm{Cs}$ is a by-product of atmospheric nuclear weapons testing that occurred during the 1950-1970s. After deposition, it binds to fine soil particles, and is concentrated in the upper $10 \mathrm{~cm}$ of the soil profile (Peart and Walling 1988). In subsoils recently exposed by erosion ${ }^{137} \mathrm{Cs}$ is virtually absent (Wallbrink et al. 1999).

Fallout lead-210 (half-life 22 years; also known as ${ }^{210} \mathrm{~Pb}$ excess, ${ }^{210} \mathrm{~Pb}_{\mathrm{ex}}$ ) is generated from the decay of ${ }^{222} \mathrm{Rn}$ in the atmosphere. It is continually delivered to the soil surface by rainfall and is usually defined as the excess of ${ }^{210} \mathrm{~Pb}$ activity over its parent ${ }^{226} \mathrm{Ra}$. Maximum concentrations of ${ }^{210} \mathrm{~Pb}_{\mathrm{ex}}$ in soils are usually found at the surface; decreasing approximately exponentially with depth, and reaching typically undetectable levels at depths of $c .10 \mathrm{~cm}$ (Fisenne 1968). Upon deposition onto the soil surface it also binds strongly to fine grained particles (Wallbrink et al. 1999).
Fig. 1 Location and geology of the Maroochy River catchment. Soil, tributary sediment, and estuary sediment sample sites are also shown. Sediment samples are denoted with an $s$, and bank profile samples are denoted $b$. Samples MC04*** and MC05*** were collected in 2004 and 2005 , respectively

The fallout of ${ }^{137} \mathrm{Cs}$ in Australia effectively ceased by the mid 1970s, and about half of the ${ }^{210} \mathrm{~Pb}_{\mathrm{ex}}$ fallout currently detectable in soils has occurred in the last 20 years. The erosion-process tracing method involves comparing the radionuclide concentrations in samples collected from hillslopes and channels (gullies and stream banks) with concentrations in samples collected from deposited river sediments downstream. Surface soil and sediment samples collected during the Maroochy study were analysed by gamma-spectrometry to measure ${ }^{137} \mathrm{Cs}$ and ${ }^{210} \mathrm{~Pb}_{\mathrm{ex}}$ concentrations.

\section{Maroochy catchment geology}

The distinctive geochemical characteristics of the soils developed on different rock types are used to trace sediment deposited in the Maroochy River estuary. The location of the Maroochy catchment and estuary and the major rock types and their distribution is summarised in Table 1 and shown in Fig. 1. There are four major rock types in the Maroochy catchment; the Eerwah Vale Tonalite in the northern catchment, the North Arm Volcanics predominantly in the north and west of the catchment, Tertiary Basaltic volcanics that occupy the west of the catchment, and the Landsborough Sandstone which is present in the southern part of the catchment. Extensive areas of floodplain and river terrace sediments are present within the upper and central catchments along major tributaries, in particular the north Maroochy River, and Petrie, Paynter and Euldo Creeks in the south. A large estuarine floodplain dominates the eastern part of the catchment around Coolum Creek, the lower Maroochy River and the Maroochy River estuary.

\section{Methods}

Field sampling: Maroochy River estuary sediments

Samples of exposed Maroochy River estuary sediments were obtained within the tidal range along exposed banks

Table 1 Summary of major rock types in the Maroochy River estuary catchment and number of samples taken

\begin{tabular}{llll}
\hline Rock type & Age & Description & No samples \\
\hline Basaltic Volcanics & Tertiary & Mainly basalt flows & Five \\
Landsborough Sandstone & Late Triassic-Jurassic & Litho-feldspathic to quartzose & Five \\
Eerwah Vale Tonalite & Late Triassic & Tonalite, diorite & Five \\
North Arm Volcanic group & Late Triassic & Rhyolite, andesite, dacite & Ten \\
\hline
\end{tabular}




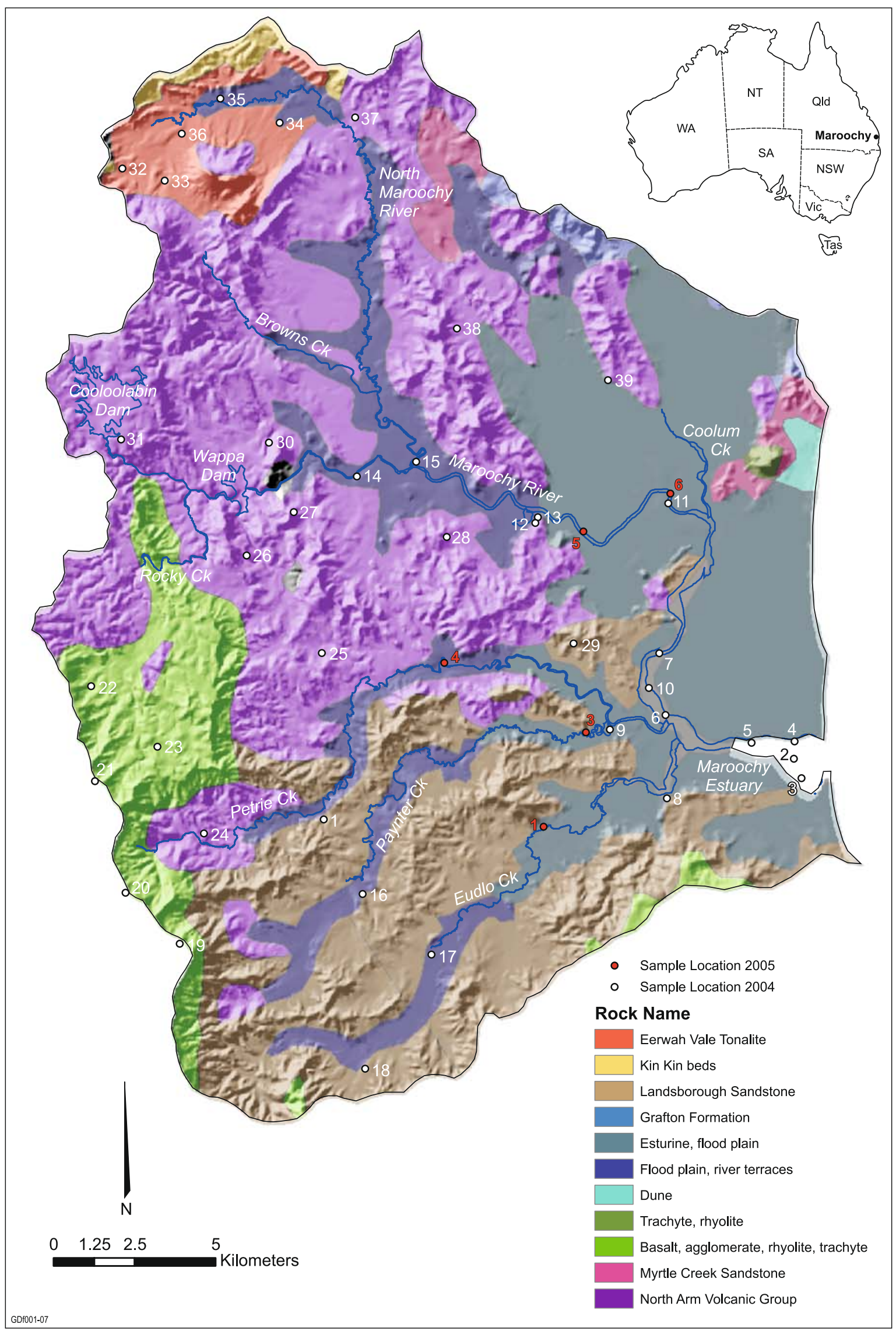


and on the edges of mangrove swamps along the estuary. All samples were collected using acid-washed plastic hand tools. Where site access allowed, multiple subsamples (typically 10-20) were aggregated to form a single sample for that site. Sample positions were recorded using a handheld GPS receiver with an estimated position error of about $10 \mathrm{~m}$. The co-ordinate system was the World Geodetic System 1984 (WGS84). Upon retrieval, sediment samples were transferred to polyethylene plastic bags and stored with ice in darkness. All estuary sediment samples were sent to the laboratory for processing chilled with ice in insulated containers. Channel bank profiles of floodplain alluvium were sampled at three locations on the upperestuarine floodplain, on or near reaches mapped as having active bank erosion (Todd 2004).

Field sampling: Maroochy catchment soils

Maroochy catchment soils were collected from pre-selected locations corresponding to major rock types using similar techniques to those of the estuary sediments. Sampling of 10-20 samples of the the upper ca. $5 \mathrm{~cm}$ of the soil profile was usually on upper hillslopes in remnant vegetation and care was taken to avoid transported soils or those of possible mixed origin. Locations were obtained with a GPS receiver as described above. Approximately, $0.5-1 \mathrm{~kg}$ of soil was collected in total and stored in plastic bags.

\section{Laboratory preparation}

Upon arrival at the laboratory, the Maroochy River estuary sediment samples and catchment soil samples were thoroughly homogenised using an acid-washed plastic spatula and representative wet samples (usually ca. 50\% of the total sample) were settled in distilled water columns assuming a density of $2.5 \mathrm{~g} / \mathrm{cm}^{3}$ to obtain a $<10 \mu \mathrm{m}$ fraction. The $<10 \mu \mathrm{m}$ sediment fraction was dried for $24 \mathrm{~h}$ in a laboratory oven at $110^{\circ} \mathrm{C}$ in acid-washed polyethylene containers. The $<10 \mu \mathrm{m}$ fraction samples were then pulverized and homogenized in a $\mathrm{WC}$ ring mill.

Major and trace element analysis

(X-ray fluorescence: XRF)

Estuary and catchment soil samples were analysed by X-ray fluorescence (XRF) for major elements (expressed as weight percent oxides): $\mathrm{SiO}_{2}, \mathrm{Al}_{2} \mathrm{O}_{3}, \mathrm{Fe}_{2} \mathrm{O}_{3}, \mathrm{MnO}, \mathrm{MgO}$, $\mathrm{CaO}, \mathrm{Na}_{2} \mathrm{O}, \mathrm{K}_{2} \mathrm{O}, \mathrm{TiO}_{2}, \mathrm{P}_{2} \mathrm{O}_{5}$, and trace elements (expressed as $\mu \mathrm{g} / \mathrm{g}$ ): As, Ba, Ce, Cl, Cr, Co, Cu, Ga, La, Ni, Pb, Rb, $\mathrm{S}, \mathrm{Sn}, \mathrm{Sr}, \mathrm{Th}, \mathrm{U}, \mathrm{V}, \mathrm{Y}, \mathrm{Zn}$ and Zr. Approximately, $1 \mathrm{~g}$ of the oven dried $\left(105^{\circ} \mathrm{C}\right)$ sample was accurately weighed with $4 \mathrm{~g}$ of 12:22 lithium (meta:tetra) borate flux. The mixture was heated to $1050^{\circ} \mathrm{C}$ in a $\mathrm{Pt} / \mathrm{Au}$ crucible for $12 \mathrm{~min}$ then poured into a $32 \mathrm{~mm} \mathrm{Pt/Au}$ mould heated to a similar temperature. The melt was cooled quickly over a compressed air stream and the resulting glass disk was analysed on a Philips PW1480 wavelength dispersive XRF system using a dual anode $\mathrm{Sc} / \mathrm{Mo}$ tube and algorithms developed in the CSIRO Land and Water, Adelaide laboratory based on the methods of Norrish and Chappell (1977).

Radionuclide sample preparation and analysis

Following the particle size separation procedure to extract the $<10 \mu \mathrm{m}$ fraction (clay and fine silt), typically $10-100 \mathrm{~g}$ of this fraction was sub-sampled for analysis and the remainder archived. The samples were then ashed in a muffle furnace at $1,000^{\circ} \mathrm{C}$ for $48 \mathrm{~h}$ to determine the loss-onignition. The powder was then pressed into moulds, and the radionuclide activities determined by routine high-resolution gamma spectrometry techniques at the CSIRO Land and Water laboratories in Canberra according to the methods of Murray et al. (1987). Gamma detector counting times were about $24 \mathrm{~h}$. Independent checks on detector calibrations were undertaken by participating in International Atomic Energy Association (IAEA) inter-comparisons.

\section{Bayesian statistical model}

The Bayesian statistical model used to determine the proportions of sediment sources in this study (Palmer and Douglas 2008) was first developed for use in a study of the origin of sediments in Moreton Bay (Douglas et al. 2003a) and has also been used to determine proportions of catchment sediment in Lake Samsonvale and Lake Wivenhoe in southeast Queensland (Douglas et al. 2003b, 2007) and the Fitzroy Estuary (Douglas et al. 2005). The Maroochy River estuary sediment samples are modelled as being comprised of varying proportions of catchment soil source material. The approach taken is to model the contribution of the sources assuming contributions in a linearly additive manner. Mathematically, for the $j$ th sample, the model can be written

$y_{j}=A z_{j}$

$A$ is a $p \times k$ matrix, where each column of $A$ corresponds to an end-member, and the elements of the vector $z_{j}$ correspond to the proportions of each end-member in the sample. The concentrations of various major elements (as wt. \% oxides) and trace elements (as $\mu \mathrm{g} / \mathrm{g}$ ) characterizes each soil or sediment sample. At each site $j$, there corresponds a $p$ column of observations $y_{j}$ and a $k$-column vector of unknown proportions $z_{j}$ of the catchment soil source types. It is postulated that the sample measurements follow a multivariate normal distribution, conditional on the proportions $z_{j}$, the distribution is 


$$
\begin{aligned}
p\left(y_{j} \mid z_{j}, A, \Gamma\right)= & (2 \pi)^{-\frac{v}{2}}|\Gamma|^{-\frac{1}{2}} \\
& \times \exp \left\{-0.5\left(y_{j}-A z_{j}\right)^{\prime} \Gamma^{-1}\left(y_{j}-A z_{j}\right)\right\} .
\end{aligned}
$$

The distribution of the unknown $z_{j}$ is modelled by assuming that the additive log-ratio transformation (alr) of the proportions follows a multivariate-normal distribution; i.e. the k-part composition vector $z_{j}$ has a logistic normal distribution

$$
\begin{array}{r}
p\left(z_{i} \mid \mu, \sum\right)=\left(\frac{1}{2 \pi}\right)^{\frac{k-1}{2}}\left|\sum\right|^{\frac{-1}{2}}\left(\frac{1}{\prod z_{i}}\right) \\
\times \exp \left[-\frac{1}{2}\left(\theta_{i}-\mu\right)^{\prime} \sum^{-1}\left(\theta_{i}-\mu\right)\right]
\end{array}
$$

and where

$$
\begin{aligned}
\theta & =\operatorname{alr}(z)=\log \left(\frac{z_{-k}}{z_{k}}\right) \\
& =\left(\log \left(\frac{z_{1}}{z_{k}}\right), \log \left(\frac{z_{2}}{z_{k}}\right), \ldots, \log \left(\frac{z_{k-1}}{z_{k}}\right)\right)
\end{aligned}
$$

A subset of the major element oxides $\left(\mathrm{SiO}_{2}, \mathrm{Al}_{2} \mathrm{O}_{3}\right.$, $\mathrm{Fe}_{2} \mathrm{O}_{3}, \mathrm{~K}_{2} \mathrm{O}, \mathrm{TiO}_{2}$ ), and trace elements $(\mathrm{Ce}, \mathrm{Cr}, \mathrm{Ga}, \mathrm{La}, \mathrm{Ni}$, Th V, Y, Zn, Zr) determined by XRF analysis were chosen to be used in the Bayesian mixing model based on a several factors. These factors included removal of elements that were usually below detection limits and elements that were not substantially different between different catchment rock/soil types, and thus were unlikely to be a diagnostic indicator of source.

In the present study, the mixing model Markov Chain Monte Carlo (MCMC) sampler was generally run for 2,000 iterations, with a burn-in of 100 after which every sample was retained, yielding 1900 model values. Examination of plots of a range of variables was made to check convergence of the samplers.

This approach to the modelling of compositions is Bayesian in nature. It explicitly models the variability associated with catchment soil samples, and this is reflected in a covariance matrix being associated with each of the soil end-members in the model (and which also accounts for possible varying numbers of samples from particular catchments). The variability associated with the compositions is derived by sampling from the joint posterior distribution of all the parameters, which includes the variability associated with the end-members.

\section{Results}

Potential sources of sediment delivered to the Maroochy River estuary were initially investigated using a statistical analysis based on the geochemistry of the catchment soil end-members. Canonical variate analysis (CVA) was used on a suite of major element oxides $\left(\mathrm{SiO}_{2}, \mathrm{Al}_{2} \mathrm{O}_{3}, \mathrm{Fe}_{2} \mathrm{O}_{3}\right.$, $\left.\mathrm{K}_{2} \mathrm{O}, \mathrm{TiO}_{2}\right)$, and trace elements $(\mathrm{Ce}, \mathrm{Cr}, \mathrm{Ga}, \mathrm{La}, \mathrm{Ni}, \mathrm{Th} \mathrm{V}$, $\mathrm{Y}, \mathrm{Zn}$ and $\mathrm{Zr}$ ). A 2D projection of a pseudo 3D plot of the first three canonical variates is presented in Fig. 2. The plot has been rotated to most clearly display the relationships between the estuary sediment and the catchment soil data.

The four major catchment end-members; soils developed on the Landsborough Sandstone, North Arm Volcanics, Eerwah Vale Tonalite and Tertiary Basalts are clearly differentiated on the basis of differences in major and trace element geochemistry (Table 2). These catchment endmembers appear to constrain the majority of the compositional variation in the estuarine and tributary samples.

Estuarine sediment samples appear to be predominantly derived from soils developed on the Landsborough Sandstone, while upper Moroochy River catchment samples appear to be composed of mixes of the North Arm Volcanics and Eerwah Vale Tonalite with little contribution from the Tertiary Basalts. One catchment sample

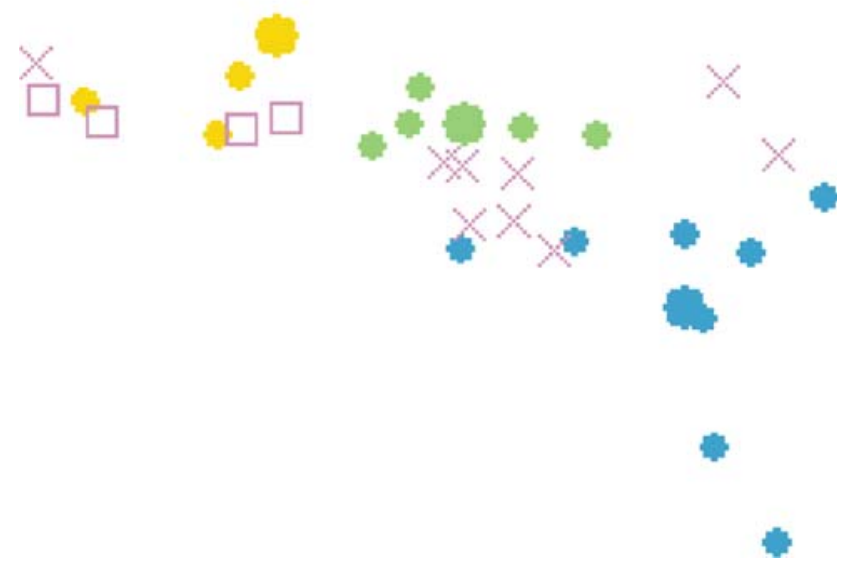

Fig. 2 Two-dimensional projection of pseudo 3D plot of canonical variate analysis (CVA) of the geochemical composition of estuary samples and major soil types in the Maroochy catchment. Soils derived from Tertiary basalts are red, Landsborough sandstone are yellow, the Eerwah Vale Tonalite are green and the North Arm Volcanics are blue. The larger symbols are means for each soil type plotted in 3D CVA space. The four purple squares are Maroochy River estuary sediment samples, nos. MC04002-5, and the nine crosses are major tributary sediment samples, nos. MC04006-15 
(MC04008, Fig. 1) appears to be predominantly composed of soil derived from Landsborough Sandstone.

Model estimates of the abundance of the four major catchment end-members present within the Maroochy River estuary sediment and their enrichment or depletion relative to their catchment area are summarised in Table 3. Pi-diagrams illustrating the relative proportions of catchment soil end-members are shown in Fig. 3.

Model estimates indicate that soils derived from the Eerwah Vale Tonalite constitute approximately one third of the sediment $(36 \pm 11 \%)$ deposited within the Maroochy River estuary. This represents an approximately 12-fold enrichment over the area of rock outcrop in the catchment (Table 3). Importantly, the Eerwah Vale Tonalite is only mapped in the far north-west of the Maroochy catchment with its only direct connection to the Maroochy River
Fig. 3 Pi-diagrams of estimated proportions of sediment derived from soils developed on major rock types (Eeerwah Vale Tonalite, North Arm Volcanic Group, Landsborough Sandstone, Basalt) in the Maroochy River, tributaries, and estuary

estuary via the North Maroochy and then Maroochy Rivers over a distance of at least 30 river kilometres.

Soils derived from the Landsborough Sandstone, which is present in the south and central Maroochy catchment, contribute about $60 \%(59 \pm 12 \%)$ of fine sediment deposited in the Maroochy River estuary (Table 3). This sediment, which is primarily sourced via the Eudlo, Paynter and Petrie Creeks, has approximately threefold enrichment over the area of rock outcrop (Fig. 3).

Soils from the North Arm Volcanics constitute only $1 \%$ of the deposited Maroochy River estuary fine sediment,
Table 2 Major and trace element geochemistry of $(<10 \mu \mathrm{m})$ soil fraction developed on major rock types in the Maroochy River estuary catchment
Detection limits are given in parentheses

\begin{tabular}{|c|c|c|c|c|}
\hline $\begin{array}{l}\text { Catchment } \\
\text { soil }\end{array}$ & $\begin{array}{l}\text { Landsborough } \\
\text { Sandstone }\end{array}$ & $\begin{array}{l}\text { Basaltic } \\
\text { Volcanics }\end{array}$ & $\begin{array}{l}\text { North } \\
\text { Arm } \\
\text { Volcanics }\end{array}$ & $\begin{array}{l}\text { Eerwah } \\
\text { Vale } \\
\text { Tonalite }\end{array}$ \\
\hline $\mathrm{SiO}_{2}(0.35)$ & 48.46 & 37.63 & 63.04 & 48.36 \\
\hline $\mathrm{Al}_{2} \mathrm{O}_{3}(0.20)$ & 19.86 & 25.18 & 15.05 & 21.77 \\
\hline $\mathrm{MgO}(0.10)$ & 0.82 & 1.47 & 0.95 & 1.17 \\
\hline $\mathrm{Fe}_{2} \mathrm{O}_{3}(0.12)$ & 7.99 & 16.15 & 4.62 & 7.11 \\
\hline $\mathrm{CaO}(0.10)$ & 0.48 & 0.43 & 0.42 & 0.80 \\
\hline $\mathrm{Na}_{2} \mathrm{O}(0.08)$ & 0.62 & 0.43 & 1.16 & 0.91 \\
\hline $\mathrm{K}_{2} \mathrm{O}(0.05)$ & 1.13 & 0.29 & 1.64 & 1.07 \\
\hline $\mathrm{TiO}_{2}(0.03)$ & 1.47 & 2.48 & 0.91 & 1.21 \\
\hline $\mathrm{P}_{2} \mathrm{O}_{5}(0.03)$ & 0.20 & 0.31 & 0.13 & 0.20 \\
\hline $\mathrm{MnO}(0.01)$ & 0.13 & 0.12 & 0.06 & 0.12 \\
\hline $\mathrm{SO}_{3}(0.02)$ & 0.06 & 0.06 & 0.04 & 0.05 \\
\hline $\mathrm{Ba}(35)$ & 306 & 195 & 311 & 262 \\
\hline $\mathrm{Ce}(20)$ & 64 & 80 & 35 & 30 \\
\hline Co (12) & 12 & 28 & 12 & 12 \\
\hline $\mathrm{Cr}(17)$ & 99 & 179 & 65 & 51 \\
\hline $\mathrm{Cu}(12)$ & 22 & 47 & 12 & 23 \\
\hline Ga (10) & 28 & 43 & 20 & 26 \\
\hline La (20) & 32 & 36 & $<20$ & 16 \\
\hline $\mathrm{Ni}(10)$ & 23 & 97 & 27 & 10 \\
\hline $\mathrm{Pb}(18)$ & 21 & $<18$ & 18 & 18 \\
\hline $\mathrm{Rb}(14)$ & 76 & 14 & 76 & 72 \\
\hline $\operatorname{Sr}(17)$ & 99 & 54 & 72 & 109 \\
\hline Th (13) & 13 & 14 & $<13$ & $<13$ \\
\hline U (13) & $<13$ & $<13$ & $<13$ & $<13$ \\
\hline V (17) & 111 & 173 & 65 & 137 \\
\hline$Y(12)$ & 23 & 31 & 42 & 25 \\
\hline Zn (18) & 81 & 129 & 66 & 106 \\
\hline $\mathrm{Zr}(30)$ & 181 & 390 & 277 & 135 \\
\hline $\mathrm{m}$ & 81.36 & 84.73 & 88.13 & 82.88 \\
\hline
\end{tabular}




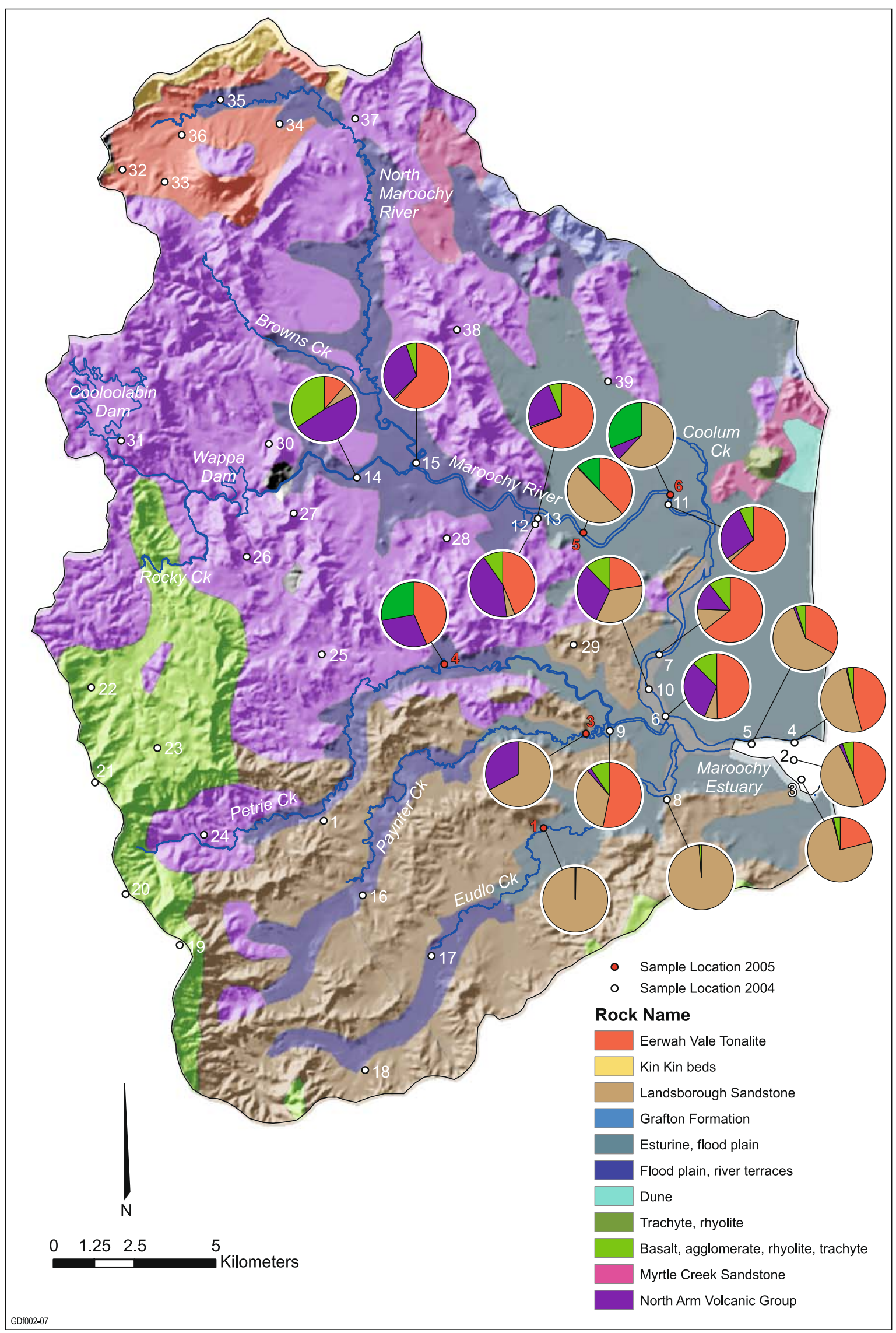


based on model estimates (Table 3). This soil source, which is drained by an extensive stream network including Petrie, Rocky and Browns Creeks and the North Maroochy and Maroochy Rivers (Fig. 3), has a depletion ratio of less than $1 / 30$ of the fine sediment deposited in the Maroochy River estuary based on the outcropping rock-type catchment area.

Model estimates indicate that soils from Tertiary Basalts constitute approximately $4 \%$ of the fine sediment within the Maroochy River estuary. The estimated abundance in the Maroochy River estuary represents a marginal depletion compared to catchment rock-type area (Table 3).

Erosion process tracing using ${ }^{210} \mathrm{~Pb}_{\mathrm{ex}}$ and ${ }^{137} \mathrm{Cs}$ was employed to determine whether topsoil (from sheet erosion) or subsoil erosion (from channel banks) was generating sediment delivered to the Maroochy River estuary. The method involved measuring the concentration of radionuclides that label topsoil due to fallout from the atmosphere, and comparing the concentrations in topsoil with the concentrations in sediment to estimate the relative topsoil and subsoil contributions.

Activities of ${ }^{210} \mathrm{~Pb}_{\mathrm{ex}}$ and ${ }^{137} \mathrm{Cs}$ measured in topsoils sampled from the Maroochy catchment and sediments sampled from the estuary are shown in Fig. 4. Also shown for comparison are activities measured in topsoils sampled from along the southeast Queensland coast. These values are consistent with the Maroochy catchment topsoil concentrations, indicating that Maroochy samples are representative of topsoil values along the region. The mean values of both topsoil data-sets are the same within the statistical uncertainty (i.e. one standard error), so the mean of all of the topsoil activities (see Fig. 4) will be used to estimate topsoil/subsoil contributions to sediment in the Maroochy River estuary.

Subsoils were expected to have very little ${ }^{210} \mathrm{~Pb}_{\mathrm{ex}}$ or ${ }^{137} \mathrm{Cs}$, because these radionuclides only penetrate a few centimetres into soil profiles following atmospheric fallout. We used subsoil activities sampled from channel banks in south-eastern Queensland, in the adjacent Brisbane River, and Logan River catchments. As expected, low activities of ${ }^{210} \mathrm{~Pb}_{\mathrm{ex}}$ and ${ }^{137} \mathrm{Cs}$ are measured from complete bank profiles because the radionuclides are only likely to be present in the top few centimetres. These activities are equivalent

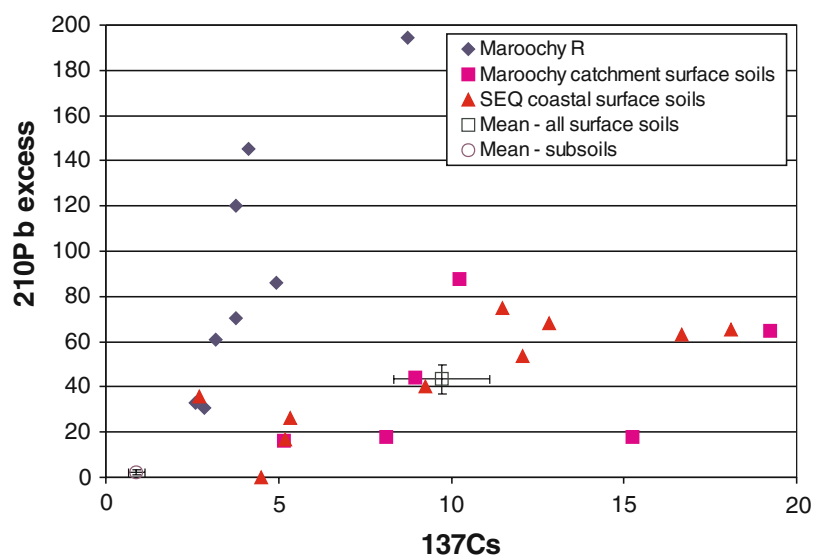

Fig. $4{ }^{210} \mathrm{~Pb}_{\mathrm{ex}}$ and ${ }^{137} \mathrm{Cs}$ activities measured from Maroochy catchment topsoils, Maroochy River/estuary sediment and coastal southeast Queensland topsoils

to values that would be measured in sediment originating from a complete bank collapse, while near-zero values would be expected from lower-bank erosion that did not include topsoil.

The spread of ${ }^{137} \mathrm{Cs}$ activities in the Maroochy River estuary samples (mean $3.6 \pm 0.3$ ) is relatively small (excluding the highest activity sample, Fig. 4), but ${ }^{210} \mathrm{~Pb}_{\mathrm{ex}}$ activities are much more varied, with three samples having substantially greater activities than those measured in topsoils. Also the ratio of ${ }^{210} \mathrm{~Pb}_{\mathrm{ex}}$ to ${ }^{137} \mathrm{Cs}$ is significantly higher in all estuary $(21.8 \pm 4.8)$ compared to the topsoil (4.5 \pm 0.9$)$ samples. Wallbrink et al. (2002) concluded that higher ${ }^{210} \mathrm{~Pb}_{\mathrm{ex}}$ activities (and higher ${ }^{210} \mathrm{~Pb}_{\mathrm{ex}}$ to ${ }^{137} \mathrm{Cs}$ ratios) are due to the residence time of sediment deposited in channels, or in this case the Maroochy River estuary. Sample 3, obtained from a mangrove island near the mouth of the estuary, has about twice the activity of ${ }^{210} \mathrm{~Pb}_{\mathrm{ex}}$ of the highest value measured in topsoils. Some of the ${ }^{210} \mathrm{~Pb}_{\mathrm{ex}}$ in this sample could have been acquired if the sediment originated from topsoil, but it is also likely that at least half of the ${ }^{210} \mathrm{~Pb}_{\text {ex }}$ accumulated in situ from direct atmospheric deposition. Sample 3 also has more than twice as much ${ }^{137} \mathrm{Cs}$ as the average of the other estuary samples. Given the supporting evidence of the relatively high ${ }^{210} \mathrm{~Pb}_{\mathrm{ex}}$ activity in sample 3, we conclude that the higher ${ }^{137} \mathrm{Cs}$ activity also accumulated in situ from direct fallout when

depletion ratio based on the contributing area (Lower Maroochy River estuary values are mean values of samples MC04002-5)
Table 3 Estimated abundance $(\mu \pm 1 \sigma)$ of soils (derived from major rock/soil types) present as sediment in the lower Maroochy River estuary, major rock/soil type outcrop area, and enrichment or

\begin{tabular}{lllll}
\hline Rock/soil type & Eerwah Vale Tonalite & Landsborough Sandstone & North Arm Volcanics & Tertiary Basalt \\
\hline Lower Maroochy estuary abundance $(\%)$ & $36 \pm 11$ & $59 \pm 12$ & $1 \pm 0$ & $4 \pm 1$ \\
Rock/soil type outcrop area (\%) & 3 & 19 & 34 & 7 \\
Enrichment $(>1)$ or depletion $(<1)$ ratio & 12.0 & 3.1 & 0.03 & 0.6
\end{tabular}


${ }^{137}$ Cs was produced during the $1950-1970$ s. This indicates that the sediment at the sample 3 site was deposited at least 30 years ago (ca. mid-1970s).

The residence time of the other Maroochy River estuary samples can be estimated using the method developed by Wallbrink et al. (2002). Using their model we calculated residence times averaging between 1 and 28 years, the highest value being consistent with the minimum residence time independently estimated for sample 3 . The model residence time estimates for sample 3 are from 3 years to well in excess of 30 years.

\section{Discussion}

The spatial tracing results indicate a dominance in the lower estuary of sediment derived from soils developed on the Landsborough Sandstone. Most of this sediment originates from the southern catchment, although two bank profiles sampled in the mid-estuary have a relatively high content of sediment derived from unmapped remnants of the Landsborough Sandstone or other sandstones. One potential source is floodplain alluvium being the Myrtle Creek Sandstone in the Coolum Creek catchment.

The other major contributor to the lower estuary is sediment originating from granitic rocks, the main mapped occurrence being the Eerwah Vale Tonalite. This rock type is only mapped as having a relatively small area of outcrop, however, it may have extensively eroded in geological history and contributed disproportionately to floodplain alluvium which is now subject to channel bank erosion. A relatively high proportion of sediment from this source was measured in two bank profiles in the mid-upper Maroochy River estuary where bank erosion has been mapped. We also propose that there are unmapped occurrences of granitoids in the Petrie Creek catchment for example, where samples from the creek had a high proportion of sediment of granitic origin.

Proportions of the Eerwah Vale Tonalite are similar for all three regions within one standard deviation (36-46\%, Table 4). Most notably, this indicates that although no Eerwah Vale Tonalite is mapped in the southern catchment, it may be the original source of alluvium that makes up the current estuarine floodplain. Closer analysis of the Nambour Special 1:100,000 geological map (Anon 1999) indicates the presence of an isolated granitoid within the Landsborough Sandstone, approximately $0.5 \mathrm{~km}$ east of sample MC04008 (Fig. 3). Isolated outcrops of granitoids are also present within the headwaters of Coolum Creek and adjacent to Coolum Beach. Thus, it is possible that other granitoids lie beneath the floodplain and may represent an unknown source of granitic material, likely to be similar in composition to the Eerwah Vale Tonalite. Additional sampling of the Petrie Creek tributary in 2005 confirms the presence of an unknown source of Eerwah Vale Tonalite, or a granitic rock equivalent. The estimated abundance of $44 \%$ in sample MC05004 is consistent with that of 53\% Eerwah Vale Tonalite in the sample collected in 2004 (MC04009). It is possible that incision of the southernmost creeks into the overlying Landsborough Sandstone may also potentially encounter granitoids similar in composition to the Eerwah Vale Tonalite.

The relative distribution of the sediment derived from Landsborough Sandstone in the three regions (3-59\%, Table 4) is generally consistent within its mapped geological distribution (Fig. 3). The relatively high Landsborough Sandstone content in two of the mid-Maroochy River estuary bank profile samples (5b and $6 \mathrm{~b}$ in Fig. 3) probably originates from small unmapped remnants of Landsborough Sandstone, as well as local contributions of sediment from the Myrtle Creek Sandstone (east of Coolum Creek), which is likely to have a similar geochemical composition to the Landsborough Sandstone. We note that there is little or no sediment of sandstone origin in the upper-mid Maroochy River estuary grab samples, but these samples represent contemporary sediment in transport, while the bank profiles have accumulated over a much longer period of floodplain deposition.

The abundance of sediment derived from the Landsborough Sandstone in tributaries on the southern estuarine floodplain reflects the mixing of the tributaries like Petrie Creek with relatively less sandstone, and tributaries such as Eudlo and Paynter Creeks that contain a substantially higher Landsborough Sandstone component. The high proportion of Landsborough Sandstone-derived sediments in the lower estuary $(59 \%)$ relative to the tributaries (3-38\%) indicates

and 05001, 05003-6), and on tributaries above the estuarine floodplain (mean of samples 04012-15)

Table 4 Estimated abundance $(\mu \pm 1 \sigma)$ of major rock/soil types in the Maroochy River estuary (mean of samples 04002-5), in all tributaries on the estuarine floodplain (mean of samples 04006-11,

\begin{tabular}{llccc}
\hline Rock/soil type & Eerwah Vale Tonalite & Landsborough Sandstone & North Arm Volcanics & Tertiary Basalt \\
\hline Lower Maroochy estuary abundance (\%) & $36 \pm 11$ & $59 \pm 12$ & $1 \pm 0$ & $4 \pm 1$ \\
All tributaries on the estuarine floodplain $(\%)$ & $36 \pm 26$ & $38 \pm 33$ & $14 \pm 14$ & $12 \pm 9$ \\
$\begin{array}{l}\text { North Maroochy and tributaries above } \\
\quad \text { estuarine floodplain (\%) }\end{array}$ & $46 \pm 26$ & $3 \pm 3$ & $37 \pm 10$ & $14 \pm 14$ \\
\hline
\end{tabular}


that sediment originating from soils developed on this rock type is primarily derived from the southern and central catchment, and preferentially deposited within the lower Maroochy River estuary.

The proportion of basalt-derived sediments (the North Arm Volcanics and Tertiary Basalts) is relatively high in the mid-upper estuary and tributaries, and relatively low in the lower estuary. The implication is that while considerable North Arm Volcanics (maximum value 37\%, Table 4), and to a lesser extent Tertiary Basalt (maximum value $14 \%$ ) derived soils are transported to the tributaries, the fine fraction of these soils are preferentially transported through the estuary to the ocean. This preferential loss may relate to the mineralogy of the sediment, particularly if fine aggregates are present that may have lower density (e.g. typically $1.1-2.0 \mathrm{~g} / \mathrm{cm}^{3}$, Sarli et al. 2001) and are thus more easily transported. The preferential loss of basaltic soils has also been observed in other Queensland estuaries (Douglas et al. 2005), and is related to the high clay (particularly smectite) content, increased dispersivity, and hence the formation of unstable soils (e.g. Lado and Ben-Hur 2004). In contrast to the less dense clays derived from the North Arm Volcanics and Tertiary Basalts, quartz, and to a lesser extent, feldspar present in the other soil/sediment types will retain a (marginally) higher density throughout the weathering cycle and is likely to be preferentially deposited in the Maroochy River estuary. The flocculation characteristics of the different clays in estuary water that is likely to be different in more saline waters in the lower estuary. In particular, smectite may be fractionated from other clays such as illite during flocculation.

Sediment derived from soils developed on North Arm Volcanic Group rocks contribute disproportionately less sediment to the estuary relative to their mapped extent. Soils developed on volcanic (trachyte, rhyolite) rocks on the south-eastern edge of the catchment also contribute relatively little sediment to the estuary.

Erosion process tracing indicates that most of the sediment (approximately 70\%) delivered to the estuary is derived from subsoil erosion. Bank erosion has been mapped along the upper Maroochy River estuary. So if eroded, bank sediment will be readily available for transport to the lower estuary. However, this is unlikely to be the only possible subsoil source.

We infer that a proportion of the ${ }^{210} \mathrm{~Pb}_{\mathrm{ex}}$ in the estuary samples is derived from in situ deposition, and that sediment residence times are probably $<30$ years for all of the samples, with the exception of sample 3 which may be older than 30 years. Residence times of this order indicate that sediment accumulation rates are relatively low along the exposed banks and edges of mangrove swamps where the samples were taken.
Our analysis shows that the ${ }^{210} \mathrm{~Pb}_{\mathrm{ex}}$ concentrations cannot be used to estimate how much topsoil is in the estuary sediments, because of the likelihood that at least part of the ${ }^{210} \mathrm{~Pb}_{\mathrm{ex}}$ concentration has accumulated in situ due to on-going atmospheric deposition (Oldfield et al. 1984). To estimate the topsoil contribution to the estuary sediments we can use the mean values of the ${ }^{137} \mathrm{Cs}$ topsoil, subsoil, and estuary sediment measurements (excluding sample 3 which is likely to have acquired ${ }^{137} \mathrm{Cs}$ in situ). From this two component mix we calculate that the average topsoil contribution to sediment sampled from the Maroochy River estuary is $30 \pm 10 \%$, therefore most of the sediment originates from subsoil erosion.

\section{Conclusions}

This study has combined the two current state-of-the-art approaches to sediment source tracing using sediment geochemistry. Major and trace element geochemistry was coupled to a Bayesian mixing model to determine the spatial sources of sediment, while radionuclides that label surface soils were used to determine whether surface erosion from topsoils, or subsoil erosion was the dominant erosion process. Studies of this type in complex natural systems are practically limited by constraints on the number of samples that can be analysed, so there is normally some degree of uncertainty in the outcomes. Nonetheless, a combined geochemical and modelling approach has been used with some success to study sediment sources in a number of other aquatic systems such as estuaries (Douglas et al. 2003a, 2005), dams (Douglas et al. 2003b, 2007) and rivers (Collins and Walling 2002; Douglas et al. 2005).

There are a number of implications from this study for the current and future management of the Maroochy River catchment and estuary. Subsoil erosion is the major source of sediment in the lower Maroochy River estuary, but active bank erosion has only been mapped along the upper estuary. This is an obvious location to target remedial management, but other areas of active channel erosion (gullies and stream banks) in the catchment should be mapped so that management strategies can be effectively targeted.

Given that most of the sediment in the lower estuary also originates from soils developed on the Landsborough Sandstone, then the Paynter and Eudlo Creek catchments where this rock type mainly occurs, are also a logical locations to target active subsoil erosion. The other major source in the mid-lower estuary is sediment originating from granitic rocks, notably the Eerwah Vale Tonalite. Channel erosion in the outcropping area of this rock type should be assessed, but it seems likely based on two of the bank profile results, that sediment derived from this source 
is also present in the upper estuarine floodplain where active bank erosion is occurring.

We have concluded that sediment residence times are probably long, possibly up to 30 years, and by inference that sediment accumulation rates are relatively low along the margins of the lower estuary. A further inference may be that rates of erosion and sediment delivery are also relatively low in the catchment, but we do not have data about sediment accumulation dynamics in the estuary, particularly during floods when most sediment will be transported. Rates of erosion in the catchment and sediment delivery to the estuary can only be quantified with reasonable certainty by long-term load monitoring on the Maroochy River and its major tributaries to develop a sediment budget.

Acknowledgments This study was funded through the Moreton Bay Waterways and Catchments Partnership. We gratefully acknowledge the assistance of Danny Hunt, Colin McLachlan, Chris Leslie, and Tenten Pinchand.

Open Access This article is distributed under the terms of the Creative Commons Attribution Noncommercial License which permits any noncommercial use, distribution, and reproduction in any medium, provided the original author(s) and source are credited.

\section{References}

Anon (1999) Nambour special 1:100,000 geology mapsheet 9444 and part 9544. Queensland Department of Mines and Energy

Cloern JE (1996) Phytoplankton bloom dynamics in coastal ecosystems: a review with some general lessons from sustained investigation of San Francisco Bay, California. Rev Geophys 34:127-168

Collins AL, Walling DE (2002) Selecting fingerprint properties for discriminating potential suspended sediment sources in river basins. J Hydrol 261:218-244

Collins AL, Walling DE (2004) Documenting catchment suspended sediment sources: problems, approaches and prospects. Prog Phys Geol 28:159-196

Diaz-Pulido G, McCook LJ (2005) Effects of nutrient enhancement on the fecundity of a coral reef macroalga. J Exp Mar Biol Ecol 317:13-24

Douglas GB, Palmer MJ, Caitcheon G (2003a) The provenance of sediments in Moreton Bay, Australia: a synthesis of major, trace element and $\mathrm{Sr}-\mathrm{Nd}-\mathrm{Pb}$ isotopic geochemistry, modelling and landscape analysis. Hydrol Process 494:145-152
Douglas GB, Ford PW, Jones GJ, Palmer MJ (2003b) Identification of sources of sediment to Lake Samsonvale (North Pine Dam), south east Queensland, Australia. Int Assoc Hydrol Sci Publ 279:33-42

Douglas GB, Ford PW, Palmer MJ, Noble R (2005) Identification of sediment sources in the Fitzroy River Basin and Estuary, Queensland, Australia. Technical report 13 CRC for Coastal Zone, Estuary and Waterway Management 38pp

Douglas G, Palmer M, Caitcheon G, Orr P (2007) Identification of sediment sources to Lake Wivenhoe, south east Queensland, Australia. Mar Freshw Res 58:1-18

Fisenne IM (1968) Distribution of ${ }^{210} \mathrm{~Pb}$ and ${ }^{226} \mathrm{Ra}$ in soil UCRL18140, U.S. Dept. of Energy, Washington DC, pp 145-158

Hamilton DP, Douglas GB, Adeney JA, Radke LC (2006) Seasonal changes in major ions, nutrients and chlorophyll- $a$ at two sites in the Swan River estuary, Western Australia. Mar Freshw Res 57:803-815

Lado M, Ben-Hur M (2004) Soil mineralogy effects on seal formation, runoff and soil loss. Appl Clay Sci 24:209-224

Murray AS, Marten R., Johnston A, Martin P (1987) Analysis for naturally occurring radionuclides at environmental concentrations by gamma spectrometry. J Radio Nucl Chem Art 115:263288

Norrish K, Chappell BW (1977) X-ray fluorescence spectrometry. In: Zussman J (ed.) Physical methods in determinative mineralogy. Academic Press, London, pp 201-272

Oldfield F, Appleby PG (1984) Empirical testing of ${ }^{210} \mathrm{~Pb}$-dating models. In: Haworth EY, Lund JWG (eds) Lake sediments and environmental history: studies in palaeolimnology and palaeoecology in honour of Winifred Tutin. Leicester University Press, Leicester, pp 93-124

Palmer MJ, Douglas GB (2008) A Bayesian statistical model for endmember analysis of sediment geochemistry, incorporating spatial dependencies. Appl Stat (in press)

Peart MR, Walling DE (1988) Fingerprinting sediment source: the example of a drainage basin in Devon, UK. In: Drainage basin sediment delivery. International Association of Hydrological Sciences Publication, vol 159, pp 41-54

Sarli GO, Filgueira RR, Giminez D (2001) Measurement of soil aggregate density by volume displacement in two non-mixing liquids. Soil Sci Soc Am J 65:1400-1403

Todd A (2004) Maroochy River Erosion Study: Stage 1. Analysis of Bank Erosion. Draft report prepared for the Moreton Bay Waterways and Catchments Partnership, May 2004

Wallbrink PJ, Murray AS, Olley JM (1999) Quantifying the depth sources of suspended sediment using fallout ${ }^{210} \mathrm{~Pb},{ }^{7} \mathrm{Be}$ and ${ }^{137}$ Cs. Soil Sci Soc Am J 63:369-378

Wallbrink PJ, Olley JM, Hancock G (2002) Estimating residence times of fine sediment in river channels using fallout ${ }^{210} \mathrm{~Pb}$. IAHS Publ 276:425-432

Walling DE, Woodward JC (1995) Tracing sources of suspended sediment in River Basins: a case study of the River Culm, Devon, UK. Mar Freshw Res 46:327-336 